\title{
TKI-aineistojen tehokas ja vastuullinen hyödyntäminen -työpajassa tuotettiin uusia toimintatapoja arkeen tukemaan avointa toimintakulttuuria
}

\author{
Seliina Päällysaho \\ Seinäjoen ammattikorkeakoulu \\ seliina.paallysaho@seamk.fi \\ https://orcid.org/0000-0002-3554-7773 \\ Hanna Lahtinen \\ Laurea ammattikorkeakoulu \\ hanna.lahtinen@laurea.fi \\ https://orcid.org/0000-0003-1086-8885 \\ Anne Kärki \\ Satakunnan ammattikorkeakoulu \\ anne.karki@samk.fi \\ https://orcid.org/0000-0001-9080-8481
}

Avoimuuden kehittäminen on noussut ammattikorkeakouluissa merkittäväksi tavaksi edistää tutkimus-, kehittämis- ja innovaatiotoiminnan (TKI) laatua ja yhteiskunnallista vaikuttavuutta. Tätä osaamista ja uusia toimintatapoja kehitettiin ammattikorkeakouluille suunnatussa työpajassa, joka pidettiin lokakuussa 2019 Tikkurilassa Hotelli Vantaalla.

Asiasanat: avoin tki, avoin tiede, ammattikorkeakoulut, työpajat, aineistot, vastuullisuus 
Viimeisten vuosien aikana on alettu kiinnittää huomiota hankkeissa syntyneiden tulosten ja osaamisen näkyväksi tekemiseen sekä laajempaan hyödynnettävyyteen. Tämä edellyttää kuitenkin tutkimustiedon keräämiseen ja hallintaan liittyvien käytänteiden kehittämistä laadukkaan ja avoimen aineiston tuottamiseksi.

Ammattikorkeakoulujen TKI-toiminnassa ja opetuksessa syntyy joka vuosi suuri määrä eri tyyppisiä aineistoja. Tyypilliset aineistot ovat kyselyihin, haastatteluihin ja mittauksiin perustuvia, mutta yritysyhteistyössä syntyy myös videoita, kuvia, mallinnuksia ja muita aineistoja. Yhteisten käytänteiden puuttumisen vuoksi projekteissa syntyvät aineistot eivät kuitenkaan ole aina löydettävissä tai käytettävissä varsinkaan projektin päättymisen jälkeen. Suuri osa kerätystä aineistosta jääkin uudelleen hyödyntämättä tai jopa katoaa kokonaan. Siksi TKI-aineistojen tehokas ja vastuullinen hyödyntäminen vaatii uudentyyppistä osaamista ja toimintatapoja.

Opetus- ja kulttuuriministeriön rahoittama korkeakoulutuksen kärkihanke "Ammattikorkeakoulujen avoin TKI-toiminta, oppiminen \& innovaatioekosysteemi” järjesti kaikille ammattikorkeakouluille suunnatun työpajan, jossa kehitettiin osaamista ja toimintatapoja TKI-aineistojen hyödyntämiseen. Työpaja toteutettiin kaksipäiväisenä ja se keräsi lähes 50 osallistujaa 18 ammattikorkeakoulusta, yliopistosta tai muusta organisaatiosta. Mukana työpajassa oli muun muassa ammattikorkeakoulukirjastojen henkilökuntaa, TKI-asiantuntijoita sekä opetushenkilöstöä.

\section{Datan hallintaa eri näkökulmista}

Työpaja aloitettiin yhteisellä iltapäivän mittaisella luento-osuudella, jonka avasi Arene ry:n toiminnanjohtaja Petri Lempinen. Lempinen nosti puheenvuorossaan esiin koko korkeakoulujärjestelmää koskevan tulevaisuuden haasteen: Korkeakouluikäisten määrä tulee romahtamaan useimmissa maakunnissa jo 2020-luvulla ja vie korkeakoulujärjestelmän ison muutoksen eteen. Toki haaste tulee koskemaan myös lukioita sekä ammattiopistoja. Soveltavan tutkimuksen avulla on silti mahdollista uudistua ja tuoda oleellista tietoa työelämän ja yhteiskunnan tarpeisiin.

Avoimen tieteen kehittämispäällikkö Henriikka Mustajoki Tieteellisten Seurain Valtuuskunnasta (TSV) kertoi avoimen tieteen kansallisen koordinaation toiminnasta. Muihin Euroopan maihin verrattuna Suomessa toiminta on organisoitu poikkeuksellisesti siten, että koordinointi tapahtuu tutkimuskentän yhteistyön pohjalta. Tavallista on, että koordinaatiota toteutetaan Euroopassa ministeriön tai ministerin johdolla, vaikka yhteistyötä tehtäisiinkin 
myös tutkimuskentän kanssa. Suomalaisen koordinaation keskiössä toimii Avoimen tutkimuksen kansallinen ohjausryhmä. Ryhmä koostuu suomalaisen tutkimusyhteisön organisaatioiden nimeämistä jäsenistä. Ohjausryhmä toimii yhteistyössä neljän asiantuntijaryhmän kanssa, jotka keskittyvät seuraaviin avoimen tieteen osa-alueeseen: 1) Tutkimusjulkaisujen avoimuus, 2) Toimintakulttuurin avoimuus, 3) Datan avoimuus ja 4) Oppimisen avoimuus.

Pekka Lehtovuori Tieteen tietotekniikan keskus Oy:stä (CSC) esitteli CSC:n tarjoamia palveluja avoimen TKI-toiminnan ja opetuksen tueksi. Lehtovuori antoi muun muassa konkreettisia esimerkkejä suurteholaskentapalvelujen mahdollisuuksista, joita parhaillaan hyödynnetään jo useammassa ammattikorkeakoulussa. Kajaanin datakeskukseen sijoitettava, yksi maailman tehokkaimmista supertietokoneista, tulee tuomaan edelleen lisäarvoa ammattikorkeakouluissa tehtävään TKI-toimintaan.

Myös aineistoihin liittyvät lainsäädännön asettamat reunaehdot tulee ottaa huomioon. Tietosuojalain edellyttämät rajoitteet alkavat olla ammattikorkeakouluissa jo melko hyvin hallinnassa, mutta 1.1.2019 voimaan tulleen tiedonhallintalain vaatimuksiin täytyy vielä paremmin vastata. Tästä tiedonhallintaan ja tietojärjestelmien käyttöön viranomaistoiminnassa sovellettavasta yleislaista kertoi Timo Pirtilä Keski-Uudenmaan sote -kuntayhtymästä. Kyseisen lain tavoitteena on vastata tietojen turvallisesta elinkaaresta etenkin asiakkaan näkökulmasta.

Turkka Näppilä Tampereen yliopistosta kertoi datan hallinnan asiantuntijoiden roolista yliopistojen tutkimushankkeissa. Kyseisiä tehtävänimikkeitä on toistaiseksi muutamia etenkin yliopistojen ja ammattikorkeakoulujen yhteisissä kirjastopalveluissa, mutta laajemmin ammattikorkeakoulukentällä niitä ei ole vielä juuri käytössä. Tosin tehtäväkuva paljastui hyvinkin tutuksi Näppilän avatessa sitä tarkemmin. Datamäärien kasvaminen ja tutkijoiden lukuisat kysymykset vaatinevat sen, että myös ammattikorkeakouluissa tullaan tarvitsemaan erilaisia tukihenkilöitä datahallinnan palveluihin liittyen. Tuen ja palveluiden mahdollistamista onkin kartoitettu ja suunniteltu myös Ammattikorkeakoulujen avoin TKI-toiminta, oppiminen \& innovaatioekosysteemi -hankkeessa.

\section{Ryhmät miettivät ratkaisuja}

Työpajassa pohdittiin myös konkreettisella tasolla TKI-aineistojen hyödyntämiseen liittyviä kysymyksiä. Osallistujat jakautuivat kolmeen ryhmään, jotka käsittelivät seuraavia teemoja: 
- CSC:n tarjoamien datanhallintaa tukevien palvelujen hyödyntäminen (mm. FAIR-datapalvelut ja arkaluonteisille aineistolle suunnatut palvelut) - miten saada palvelut tehokäyttöön myös ammattikorkeakouluissa?

- Opinnäytetöissä kerätyt aineistot - miten niitä pitäisi hallita ja kannattaako niitä tallentaa tai avata? Mitä kaikkea prosessi vaatii ja mitä täytyy huomioida (luvat, sopimukset, omistajuus)?

- Datanhallinta yritysyhteistyöhankkeissa - mihin velvoittavat $\mathrm{mm}$. tietosuoja, tiedonhallintalaki tai etiikka? Onko aineistoja mahdollista avata ja jatkokäyttää?

CSC:n vetämässä ryhmässä keskusteltiin datan eri olomuodoista ja pohdittiin, miten dataa voi avata hallitusti ja harkitusti. Jos varsinaisen datan avaaminen ei onnistu, niin siihen liittyvän metadatan avaaminen on yleensä mahdollista. Tunnisteet ovat datan löytymisen kannalta oleellisia, mutta ammattikorkeakoulut eivät ole niitä toistaiseksi juurikaan käyttäneet. FAIR-periaatteiden (eli löydettävä, saavutettava, yhteentoimiva ja uudelleenkäytettävä) tunnistaminen on olennaista datojen kanssa työskenneltäessä1.

Opinnäytetöiden aineistoja pohtivassa ryhmässä tarkasteltiin koko opinnäytetyön elinkaarta. Työpajassa käytettiin case-esimerkkinä kuvitteellista opinnäytetyötä, jossa kohdistettiin interventiotutkimus lapsiin. Prosessia läpikäytäessä huomattiin, että kiperiä kysymyksiä nousee esiin esimerkiksi omistajuuteen ja vastuisiin liittyvissä asioissa. Muun muassa tietosuojaan liittyvien asioiden kohdalla todettiin, että tarvitaan selkeitä ohjeita opinnäytetyön tekijöille ja ohjaajille koulutusta.

Datanhallinta yritysyhteistyöhankkeissa vaatii hyvää tietosuojan, tiedonhallintalain ja eettisten asioiden tuntemusta. Ennakointi, suunnitelmallisuus ja asioista sopiminen nousivat oleellisina asioina esiin. Työpajan aikana kehitettiin learning cafe -menetelmän avulla avoimen TKI-toiminnan prosessin eri vaiheisiin pohjautuvaa tarkistuslistaa, jota ammattikorkeakoulut voivat hyödyntää suunniteltaessa yritysyhteistyöhankkeiden datanhallintaa.

\section{Näkökulmia jatkotyöskentelyyn}

Työpaja nosti esiin tärkeitä teemoja liittyen ammattikorkeakoulujen aineistoihin ja niiden hyödyntämiseen. Vaikka valtakunnan tasoisia yhteisiä datan hallinnan palveluja on saatavilla, se ei poista täysin tarpeita ammattikorkeakoulujen omien tutkimusinfrastruktuurien kehitystyöltä. Oleellista on 
esimerkiksi kehittää soveltuvia metadatakäytänteitä. Ammattikorkeakoulujen aineistot kiinnostavat usein yrityksiä, joten kuvailutietojen tulee olla ymmärrettäviä myös niiden näkökulmasta. Huomioivatko yhteiset FAIR-periaatteet tämän kyllin hyvin? Vai pitäisikö ohjeistusta muokata paremmin ammattikorkeakouluille soveltuviksi?

Myös opinnäytetöiden aineistoihin liittyy vielä paljon pohdittavaa koskien aineistojen keruun luotettavuutta ja aineistojen laatua. Osaamista täytyy kehittää etenkin kerättäessä ja tallennettaessa arkaluonteisia aineistoja. Tällä hetkellä ammattikorkeakoulut ottavat käyttöön jo omia tietosuojaohjeistuksiaan ja pohtivat aineistonhallintasuunnitelmien systemaattista tekemistä. Opinnäytetöistä syntyvien aineistojen laadun parantaminen edellyttää niin opinnäytetöiden tekijöiden osaamisen kuin ohjaajien osaamisen kehittymistä. Kerättävien aineistojen luotettavuus on vaatimuksena mahdolliselle avaamiselle tai jatkokäytölle.

Vaikka ammattikorkeakouluilla on pitkä historia yritysten kanssa yhteistyössä toteutettavista projekteista, kannattaa yhteistyössä syntyvien aineistojen hyödyntämistä edelleen kehittää. Useat aineistot voivat jäädä hyödyntämättä esimerkiksi siksi, että pelätään turhaan niiden avaamista tai muille jakamista. Liiketoimintaa ei kuitenkaan tehdä pelkillä avoimilla aineistoilla, vaan esimerkiksi niihin liittyvillä algoritmeillä ja käyttöliittymillä. Aineistojen avaamisen sopiminen yritysyhteistyössä jo ennen projektin aloittamista on sekä yrityksen että ammattikorkeakoulun etu.

\section{Työpajan tulokset kaikkien kiinnostuneiden saatavilla}

Kahden päivän aikana ehdittiin syventyä moniin eri näkökulmiin ja läpi käydyn tiedon määrä oli mittava. Työpajan tuloksia on jaettu avoimesti laajalle joukolle työpajan jälkeen järjestetyn Tulos-webinaarin avulla. Tähän webinaariin kutsuttiin mukaan varsinaiseen työpajaan osallistuneet sekä avoimella kutsulla myös kaikki muut teemasta kiinnostuneet. Tunnin mittaisessa virtuaalitilaisuudessa jokaisen kolmen työskentelyryhmän vetäjät tiivistivät lyhyesti työpajan sisällön ja esittelivät tärkeimmät tulokset ja havainnot. Webinaarin nauhoite on katsottavissa hankkeen avoimessa työtilassa Eduuni-workspaces-palvelussa ${ }^{2}$, josta löytyy myös muuta hankkeeseen liittyvää materiaalia.

Työpaja mahdollisti yhteisen keskustelun ja kokemusten jakamisen TKI-aineistojen avaamisen ja hyödyntämisen haasteista sekä tuotti uutta 
osaamista, välineitä ja toimintamalleja arkeen. Kenttä on laaja, ja edelleen parhaimpien toimintatapojen kehittäminen vaatii yhdessä työskentelyä sekä tehokasta tiedonkulkua. Koko ammattikorkeakoulusektorille suunnatut, ja kaikille avoimet, työpajat toimivat erinomaisena kehitysalustana tässä työssä.

Tämä artikkeli on kirjoitettu osana Ammattikorkeakoulujen avoin TKI, oppiminen \& innovaatioekosysteemi -hanketta, joka on opetus- ja kulttuuriministeriön rahoittama korkeakoulutuksen kärkihanke. Hanketta koordinoi Seinäjoen ammattikorkeakoulu. 